\title{
STRATEGI PEMASARAN AGROINDUSTRI DODOL RASA BUAH LOKAL
}

\author{
Agroindustry Marketing Strategy of Local Fruit Taste Dodol
}

\author{
DEBBY ANGGINA*1, NOVIA DEWI ${ }^{2}$, DAN FAJAR RESTUHADI ${ }^{3}$ \\ 1,2,3 Program Pascasarjana, Magister Agribisnis, Universitas Riau, Indonesia \\ Kampus Bina Widya KM. 12.5, Simpang Baru, Kec. Tampan, Kota Pekanbaru, Riau 28293 \\ E-mail: angina.debby@gmail.com
}

\begin{abstract}
ABSTRAK
Penelitian ini bertujuan untuk merumuskan strategi pemasaran dodol buah di Kabupaten Siak. Penelitian ini menggunakan metode survei. Pemilihan responden pada penelitian ini dilakukan secara sengaja (purposive sampling). Penentuan responden berdasarkan kepakaran dan perannya dalam pengambilan kebijakan yang berkaitan dengan agroindustri dodol buah. Analisis data menggunakan analisis Multidimensional Scaling (Mds), prospektif dan Analitic Hierarchi Process /AHP. Hasil analisis menunjukkan bahwa faktor penentu pengelolaan bauran pemasaran dodol buah terdiri atas; dimensi produk, harga, promosi, dan distribusi. Atribut pengungkit dalam pengelolaan bauran pemasaran dodol buah di Kabupaten Siak diperoleh bahwa tipe sebaran cenderung mengumpul di kuadran I dan kuadran III. Strategi pemasaran dodol buah di Kabupaten Siak kegiatan promosi terdiri dari semua kegiatan pemasaran yang mencoba terjadinya aksi pembelian suatu produk yang cepat atau terjadinya pembelian dalam waktu yang singkat.
\end{abstract}

Kata Kunci: Faktor penentu; pengelolaan bauran pemasaran, strategi pemasaran

\section{ABSTRACT}

This research was designed to formulate the marketing strategy of dodol fruit in Siak Regency. This research used a survey method. The selection of respondents in this study was done intentionally or it is called purposive sampling. The respondents were chosen by regarding expertise and their role in making a policy relating to fruit dodol agroindustry. And the data analysis used Multidimensional Scaling (Mds), prospective and Analytical Hierarchical Process / AHP analysis. The analysis result determined that the determinants of managing the marketing mixed of pineapple consist of product, price, promotion and distribution. Furthermore, the lever attribute in the management of the marketing mixed of dodol fruit in Siak Regency was obtained the distribution of collecting were in first quadrant and third quadrant. The marketing strategy of dodol fruit in Siak Regency were promotional activities consist of all marketing activities that discuss the action of purchasing products quickly or buying in a short time.

Keywords: Determinants; marketing mixed management, marketing strategy

Diterima : 15 April 2020. Disetujui: 15 Agustus 2020

\section{PENDAHULUAN}

Soekartawi (2009) menjelaskan bahwa paling tidak, ada empat strategi sektor pertanian mampu berkontribusi menghadapi krisis finansial global yang lalu yaitu: (a) Mampu berkontribusi dalam mendorong pertumbuhan ekonomi, seperti meningkatkan produksi pertanian, peternakan, perikanan, perkebunan dan kehutanan, di samping menggerakkan pasar domestik, dan tetap melakukan ekspor. (b) Mampu berkontribusi mengurangi pengangguran di pedesaan, yaitu dengan tetap menggerakan sektor pertanian dan sektor riil seperti agroindustri. (c) Mampu 
berkontribusi mengurangi kemiskinan dengan meningkatkan pendapatan, (d) Mampu berkontribusi menciptakan kegiatan produktif agar menarik investor di bidang pertanian atau industri berbasis pertanian (agro-industri). Dengan demikian kebutuhan pengembangan agroindustri yang banyak menggunakan bahan baku lokal dan berbasis pada pertanian akan semakin penting untuk dilaksanakan.

Agroindustri sebagai suatu usaha untuk menciptakan nilai tambah bagi komoditi pertanian antara lain melalui produk olahan dalam bentuk setengah jadi maupun barang jadi yang bahan bakunya berasal dari hasil pertanian. Usaha-usaha pengembangan pertanian yang mengarah pada kegiatan agroindustri yaitu pengolahan hasil pertanian menjadi bahan makanan, salah satu produk pertanian yang dapat diolah yaitu Jahe, Kacang Hijau, Nanas dan Buah Naga. Jenis buah tersebut bisa dijadikan dodol oleh masyarakat di Kabupaten Siak.

Dodol merupakan salah satu jenis makanan tradisional yang namanya sudah banyak dikenal oleh seluruh masyarakat Indonesia. Dodol dibuat denggan menggunakan ketan, kelapa dan gula merah. Dodol memiliki cita rasa legit dan manis. Buah naga dan nenas yang merupakan salah satu buah yang banyak ditanam didaerah tropis dan sub tropis. Nanas selain digunakan sebagai bahan dasar dari pembuatan dodol.

Dodol buah terbuat dari daging buah matang yang dihancurkan, kemudian dimasak dengan penambahan gula dan bahan makanan lainnya atau tanpa penamabahan makanan lainnya. Sesuai dengan defenisi tersebut maka dalam pembuatan dodol buah-buahan diperbolehkan penambahan bahan lainnya, seperti tepung ketan, tepung tapioca, tepung hunkue, bahan pewarna, maupun bahan pengawet. Bahan-bahan yang ditambahkan harus sesuai dan tidak boleh lebih dari aturan yang telah ditentukan.
Demi mewujudkan agribisnis efisien dan efektif maka dibutuhkan pemasaran yang baik agar dapat meningkatkan pendapatan petani dan pengusaha dodol buah. Ciri penting dari agroindustri adalah kegiatannya tidak tergantung musim, membutuhkan manajemen usaha yang modern, pencapaian skala usaha yang optimal dan efisien, serta mampu menciptakan nilai tambah yang tinggi (Hasyim dan Zakaria, 1995).

Agroindustri dodol buah harus dapat memasarkan barang atau jasa yang diproduksi kepada konsumen agar dapat bertahan dan bersaing dengan usaha lainnya. Kotler dan Amstrong (2001) kualitas produk merupakan senjata strategis yang potensial untuk mengalahkan pesaing. Hanya agroindustri dengan kualitas produk paling baik yang akan tumbuh dengan pesat, dan jangka panjang perusahaan tersebut akan lebih berhasil dari perusahaan yang lain.

Potensi yang dimiliki oleh Kabupaten Siak dari segi produksi dodol buah seharusnya mampu membuat agroindustri dodol buah menjadi icon dari Riau dan seharusnya mampu melakukan penjualan hingga luar kota maupun luar pulau. Salah satu penyebabnya ialah promosi yang dilakukan para pengrajin dodol buah di Desa Buantan Besar belum maksimal. Promosi yang maksimal tentunya akan berdampak pada volume penjualan.

Pembeli ada yang membeli produk karena harga yang murah, mutu yang tinggi, kualitas yang baik, serta mudahnya menemukan informasi mengenai produk, seseorang tentunya akan mempertimbangkan jarak yang dekat, toko yang lengkap, susunan barang-barang yang menarik, pelayanan yang memuaskan maupun tempat belanja yang kondusif. Agroindustri dodol buah di Desa Buantan Besar letaknya memang berada di pinggir jalan besar, namun penataan kios serta kebersihan toko masih kurang terperhatikan. 
Selain permasalahan di atas, terdapat permalahan lain berkaitan dengan strategi pemasaran. Penelusuran awal terhadap volume penjualan dari produk dodol buah tersebut kurang memberikan hasil yang signifikan. Hal ini dapat dilihat dari perbandingan antara penjualan dengan produk yang ada tidak seimbang. Rendahnya kapasitas produksi, terbatasnya wilayah distribusi, rendahnya omset penjualan yang diperoleh, minimnya sarana prasarana yang dimiliki dan lain sebagainya yang terbilang masih sangat rendah untuk sebuah usaha yang sudah berjalan selama puluhan tahun. Sehubungan dengan permasalahan tersebut penelitian ini bertujuan untuk menganalisis atribut pengungkit dalam pemasaran dodol buah dan merumuskan strategi pengelolaan bauran pemasaran dodol buah.

\section{METODE PENELITIAN}

\section{Tempat dan Waktu Penelitian}

Penelitian ini dilakukan konsumen yang membeli dodol buah dari Kecamatan Siak Kabupaten Siak Provinsi Riau. Pemilihan lokasi ini dilakukan dengan pertimbangan industri rumah tangga dodol buah tersebut memiliki potensi yang besar untuk dikembangkan. Penelitian ini dilaksanakan selama dua bulan, dimulai pada bulan September 2018 sampai November 2018

\section{Pengambilan Sampel dan Data}

Pengambilan sampel yang dilakukan dalam penelitian ini terbagi menjadi dua yaitu, responden internal dan responden eksternal. Penentuan responden internal menggunakan metode purposive sampling. Dimana responden dipilih secara sengaja dengan pertimbangan bahwa responden merupakan pihak yang paham dan mengerti mengenai kondisi pemasaran dodol buah UD. Putra Mandiri atau disebut sebagai key informan. Penentuan responden eksternal dilakukan dengan metode sampling insidentil dimana setiap pembeli yang ditemui dijadikan sebagai sampel dengan mencatat bahwa sampel tersebut cukup mewakili populasi dengan pertimbangan biaya dan waktu. Oleh karena itu, jumlah sampel dalam penelitian ini ditetapkan sebanyak 35 orang.

Data yang digunakan pada penelitian ini, merupakan data primer dan data sekunder. Data primer diperoleh dengan cara pengamatan langsung di lokasi penelitian, serta wawancara dengan anggota UD. Putra Mandiri ataupun pihak pelaku industri. Sedangkan data sekunder, diperoleh dari Dinas terkait dan sumber referensi yang mendukung penelitian ini.

\section{Metode Analisis Data}

Metode analisis yang digunakan pada penelitian ini adalah Multidimensional Scaling (Mds), Analisis prospektif dan Analisis AHP.

\section{Analisis Prospektif}

Analisis prospektif merupakan suatu metode yang digunakan untuk menganalisis permasalahan dalam sistem ahli yang dapat menggabungkan pembuat keputusan dalam rangka menyusun kembali beberapa perencanaan dengan pendekatan yang berbeda (Bourgeois dan Jesus; 2004). Analisis prospektif bertujuan untuk menentukan kedudukan dari atribut-atribut pengungkit sehingga akan diperoleh atribut kunci atau faktor penentu (driving variables). Out put analisis prospektif akan diperoleh 4 (empat) kuadran yang merupakan kedudukan atribut-atribut pengungkit, seperti Gambar 1. 


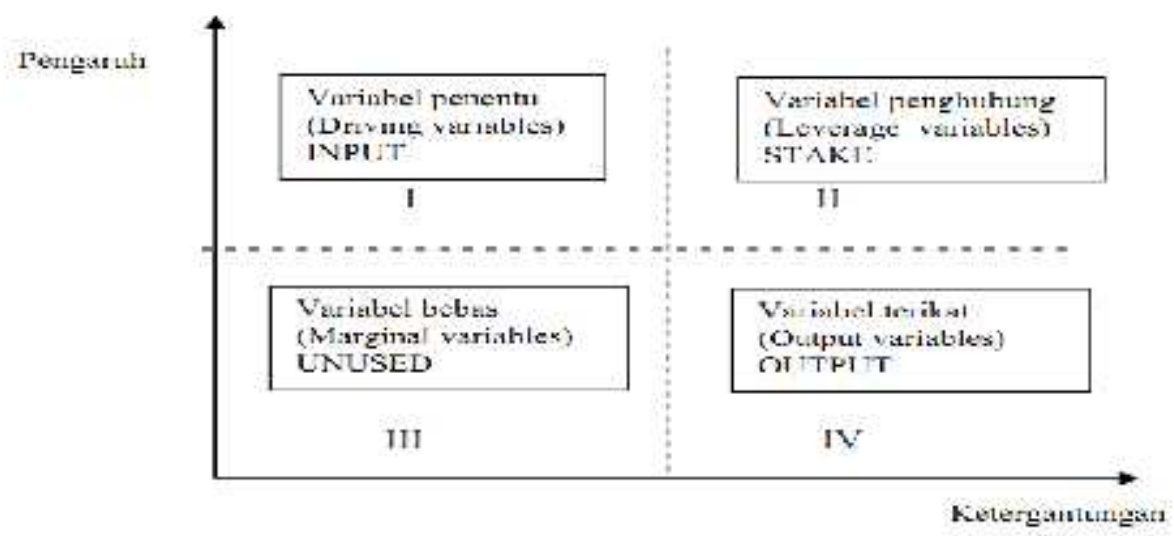

Gambar 1. Tingkat Kepentingan Faktor

Keterangan:

a) Kuadran-I adalah kuadran input yang merupakan kuadran variabel penentu (driving variables). Kuadran ini memuat atribut-atribut yang memiliki pengaruh kuat dan ketergantungan antar atribut rendah.

b) Kuadran-II adalah kuadran stake yang merupakan kuadran variabel penghubung (leverage variables). Kuadran ini memuat atribut-atribut yang memiliki pengaruh kuat dan ketergantungan antar atribut juga kuat.

c) Kuadran-III adalah kuadran output yang merupakan kuadran variabel terikat (output variables). Kuadran ini memuat atribut- atribut yang memiliki pengaruh rendah dan ketergantungan antar atribut kuat.

d) Kuadran-IV adalah kuadran unused yang merupakan kuadran variabel bebas (marginal variables). Kuadran ini memuat atribut-atribut yang memiliki pengaruh rendah dan ketergantungan antar atribut juga rendah.

\section{Multidimensional Scaling (Mds)}

Analisis Multi-Dimensional Scaling (MDS) merupakan prosedur yang digunakan untuk menggambarkan persepsi dengan stimulasi yang dilakukan secara geometris antara titik-titik ke dalam ruang dimensi dari hasil pemetaan akan diperoleh posisi persaingan yang dipersepsikan oleh konsumen (Supranto, 2010). Pasangan terdekat dianggap memiliki banyak kemiripan, sedangkan pasangan terjauh dianggap memiliki banyak perbedaan.

\section{Analisis AHP}

Analisis data menggunakan Analitic Hierarchi Process (AHP) merupakan suatu model pendukung keputusan yang dikembangkan oleh Thomas L. Saaty. Model ini akan menguraikan masalah multi faktor yang kompleks menjadi suatu hirarki.

\section{HASIL DAN PEMBAHASAN}

\section{Analisis Multidimensional Scaling (Mds)}

Persepsi konsumen didasarkan pada atribut merk dodol buah yang dapat dilihat pada konfigurasi perceptual map. Perceptual map yang diperoleh pada Gambar 2. berikut: 


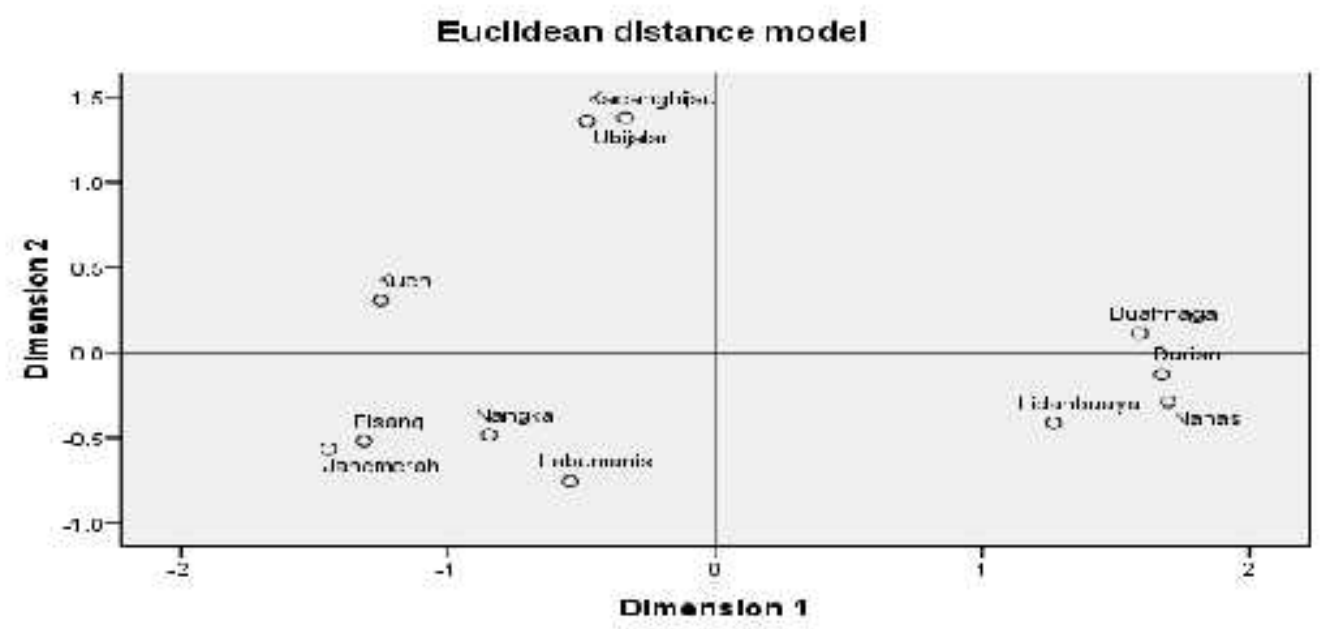

Gambar 2. Grafik MDS

\begin{abstract}
Berdasarkan gambar 2. atas menjelaskan bahwa peta hasil proses ALSCAL untuk menampilkan map MDS dari kasus di atas. Terlihat bahwa dodol buah naga terletak jauh dari keempat toko yang lain. Karena itu bisa dikatakan dodol buah naga paling berbeda jika dibandingkan dengan dua kelompok dodol durian yang lain. Dodol buah kacang hijau, ubi jalar dan mangga dianggap berada pada satu kuadran yang sama pula, sehingga keduanya juga bias dikatakan mirip. Dodol buah pisang, jahe merahm nangka dan labu manis dianggap berada pada satu kuadran yang sama pula, sehingga keduanya juga bias dikatakan mirip. Dodol lidah buaya, nanas dan durian dianggap berada pada satu kuadran yang sama pula, sehingga keduanya juga bias dikatakan mirip.
\end{abstract}

Kacang hijau dan ubi jalar memiliki banyak kemiripan atribut yang dinilai oleh konsumen, prioritas pertama konsumen lebih cenderung memilih ubi jalar, sedangkan solusinya adalah dodol kacang hijau. Kacang hijau dipilih karena dari segi rasa yang sudah umum dirasakan oleh konsumen sehingga tidak perlu mencoba-coba dan sudah membuktikan bahwa dodol rasa kacang hijau lebih enak bagi pecinta kacang.

Jika ubi jalar dan kacang hijau tidak diperoleh di gerai oleh-oleh lainnya, maka konsumen memilih alternative ke 3 yaitu dodol kueni. Alasan konsumen memilih kueni karena dodol rasa mangga ini lebih sering ada dibandingkan dengan dodol rasa buah yang lain. Selain itu, dodol buah kueini memiliki rasa yang berbeda dan memiliki rasa khas mangga sehingga banyak diminati oleh konsumen.

\section{Atribut Bauran Pemasaran Dodol Buah}

Untuk mengetahui sikap konsumen dodol buah terhadap atribut bauran pemasaran yang ditetapkan, maka harus mengetahui penilaian dari konsumen tersebut mengenai atribut-atribut yang akan di analisis dalam penelitian ini. Penilaian konsumen terhadap atribut bauran pemasaran dodol buah dapat dilihat pada Tabel 4.15 
Tabel 1. Penilaian Konsumen Terhadap Atribut Bauran Pemasaran Dodol Buah

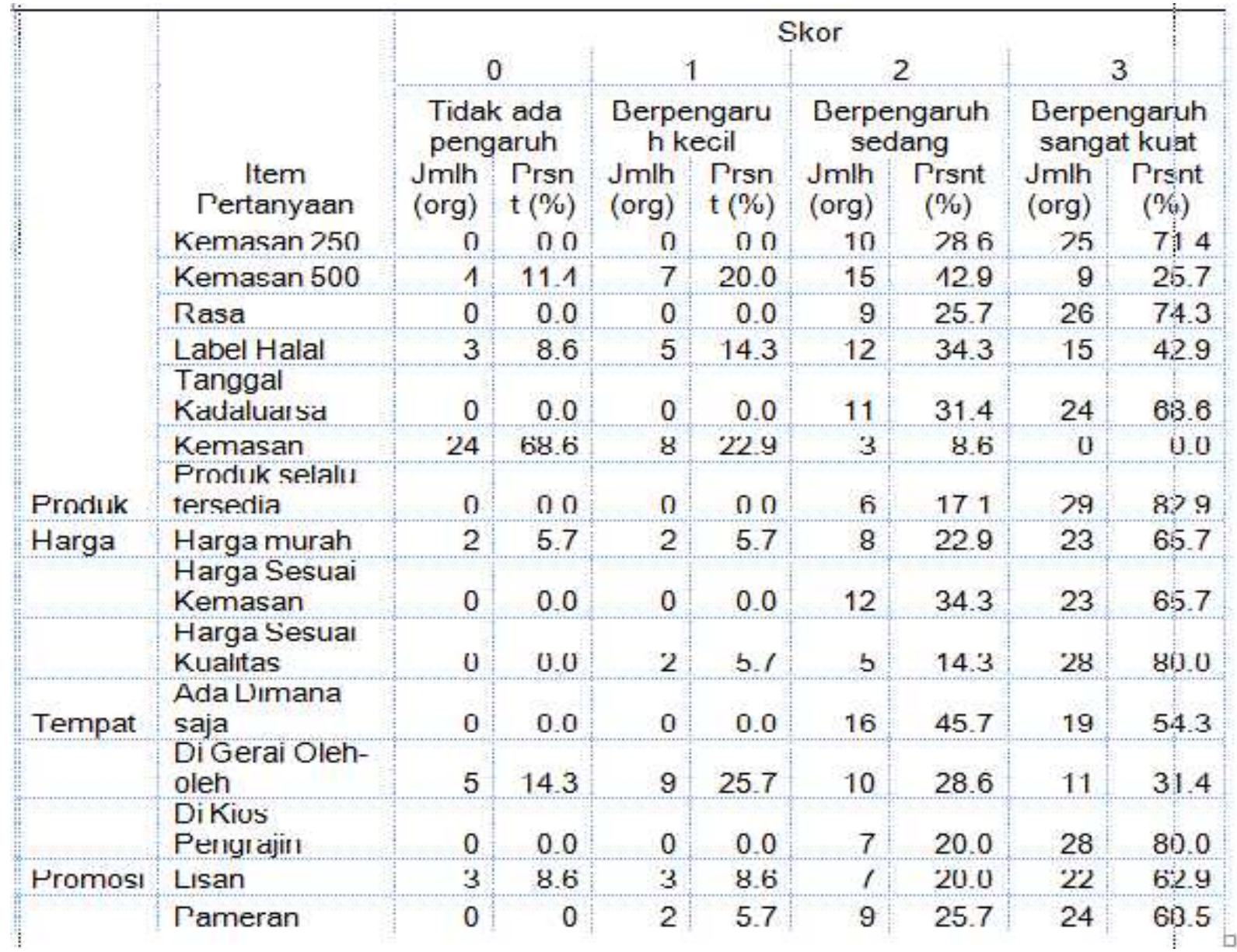

\section{Analisis Propestif}

Analisis prospektif merupakan metode yang digunakan untuk menganalisis permasalahan dalam sistem ahli yang dapat menggabungkan pembuat keputusan dalam rangka menyusun kembali beberapa perencanaan dengan pendekatan yang berbeda. Analisis prospektif bertujuan untuk menentukan kedudukan dari atribut-atribut, sehingga akan diperoleh atribut kunci. Output analisis prospektif akan diperoleh empat kuadran yang merupakan kedudukan atribut (Bourgeois dan Jesus, 2004).

Adapun sistem yang dikaji dalam penelitian ini adalah atribut penentu sikap konsumen dodol buah dan implikasi pengembangan pemasaran dodol buah di UD. Putra Mandiri. Terdapat 15 atribut dalam penelitian yaitu kemasan 250, kemasan 500, bentuk curah, rasa, warna, kemasan, produk selalu tersedia, harga murah, harga sesuai kemasan, harga sesuai kualitas, ada dimana saja, di gerai oleh-oleh, di kios pengrajin, lisan dan pameran. Atribut-atribut tersebut kemudian diberi skor pengaruh antar atribut.

Hubungan antara atribut tersebut dapat berupa pengaruhataupun ketergantungan antara atribut. Hasil analisis prospektif diperoleh seperti pada Gambar 3 Diagram pengaruh dan ketergantungan atribut dodol buah. 


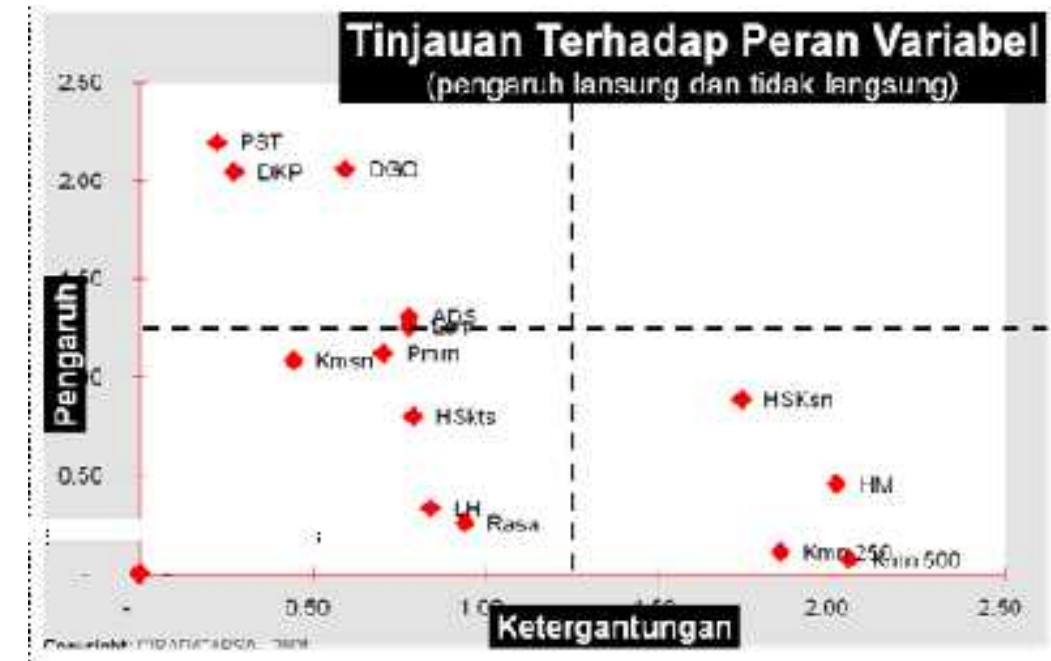

Gambar 3. Diagram pengaruh dan ketergantungan atribut dodol buah

\section{Keterangan:}

1. Kmsn 250 : Kemasan 250

2. Kmsn 500 : Kemasan 500

3. Rasa : Rasa

4. LH : Label Halal

5. TK : Tanggal Kadaluarsa

6. HM : Harga Murah

7. HSKsn : Harga Sesuai Kemasan

8. HSKts : Harga Sesuai Kualitas

9. LSN : Lisan

10. PMRN : Pameran

11. KMSN : Kemasan

12. ADS : Ada Dimana Saja

13. DGO : Di Gerai Oleh-oleh

14. DKP : Di Kios Pengrajin

15. PST : Produk Selalu Tersedia

Berdasarkan hasil analisis prospektif, seperti pada Gambar 3, diperoleh bahwa tipe sebaran cenderung mengumpul di kuadran I dan kuadran III. Atribut yang termasuk dalam variabel penentu (driving variables) terdiri atas; produk selalu ada, distribusi di kios pengrajin, tersedia di gerai oleh-oleh, tersedia dimana saja, dan promosi melalui kemasan. Atribut-atribut tersebut terletak di kuadran I, yakni atribut yang memiliki pengaruh kuat dan ketergantungan antar atribut rendah. Atribut ini merupakan atribut penentu terhadap keberhasilan pemasaran dodol buah (Resources, 2017).

Gambar 3 yang perlu diperbaiki adalah kuadran 4. Hal ini dikarenakan supaya konsumen memiliki sikap loyal. Semakin positif penilaian konsumen terhadap kemasan, maka semakin meningkatkan pembelian terhadap dodol buah. Yang perlu diperbaiki adalah dari segi kemasan 250. Hal ini dikarenakan banyak konsumen yang tidak mau ribet membawa banyak tentengan kemasan dodol. Selain itu kemasan dodol tersebut juga berbeda dengan kemasan 500 .

Kemasan 500 juga perlu diperbaiki. Hal ini dikarenakan ada beberapa konsumen yang ingin membeli dodol buah dengan bentuk curah agar dapat membagi-bagikan kepada tetangga sebagai oleh-oleh. Harga murah dodol buah yang ada di UD. Putra Mandiri juga perlu diperhatikan. Karena masih ada dodol lain yang lebih murah harganya dan memiliki rasa yang tidak kalah dengan dodol buah. Selanjutnya harga sesuai kemasan, menurut masyarakat tidak ssesuai karena tempat dodol buah biasa saja sedangkan harganya juga mahal sehingga tidak sebandingan dengan harga tersebut. 


\section{1) Promosi Penjualan}

Berdsasarkan hasil penelitian atribut promosi penjualan merupakan salah satu atribut penentu sikap konsumen dalam membeli dodol buah salah satunya melalui pameran. Hal ini dikarenakan atribut promosi penjualan memiliki pengaruh kuat dan ketergantungan antar atribut rendah. Konsumen dodol buahdi UD. Putra Mandiri beranggapan bahwa promosi penjualan menjadi pertimbangan konsumen dalam membeli dodol buahseperti promosi penjualan melalui internet yang dapat memudahkan konsumen dalam mencari informasi maupun sebagai referensi bagi konsumen. Pemberian free sampel produk saat pameran serta diskon $5 \%$ untuk konsumen yang membeli produk dodol buah dengan jumlah banyak dapat mendorong konsumen untuk melakukan pembelian. Hal ini sesuai dengan penelitian Septiana (2010), menyatakan bahwa promosi merupakan salah satu faktor penentu keberhasilan usaha pemasaran. Promosi memiliki pengaruh terhadap tingkat penjualan suatu produk perusahaan. Atribut bauran promosi yang dipertimbangkan konsumen dalam membeli dodol buah terdiri dari media promosi pemberian sampel gratis. Pemberian sampel gratis dapat mendorong konsumen untuk melakukan pembelian akan suatu produk. Pada bisnis pangan (makanan dan minuman).

\section{2) Citarasa Dodol Buah}

Citarasa dodol buah merupakan salah atribut penentu sikap konsumen dodol buah hal ini dikarenakan atribut citarasa memiliki pengaruh kuat dan ketergantungan antar atribut rendah. Konsumen dodol buah di UD. Putra Mandiri beranggapan citarasa merupakan faktor yang paling penting dan menjadi pertimbangan konsumen dalam membeli produk khususnya produk makanan. Meskipun citarasa bersifat relatif namun makanan dengan citarasa yang enak dapat menjadi unsur penting dalam menentukan kualitas makanan. Hal ini sesuai dengan penelitian Septiana (2010), menyatakan bahwa atribut produk yang berpengaruh dalam pengambilan keputusan pembelian dodol buah oleh konsumen yaitu citarasa. Konsumen menilai bahwa rasa dodol buah tersebut tergolong enak sesuai dengan rasa buah yang ada.

3) Harga Dodol buah

Harga seringkali dikaitkan dengan kualitas, konsumen cenderung untuk menggunakan harga sebagai indikator kualitas atau kepuasan potensial dari suatu produk. Harga akan mempengaruhi keputusan pembelian apabila harga suatu produk tersebut terjangkau, memiliki daya saing, sesuai dengan kualitas dan manfaat yang ditawarkan.

Harga dodol buah merupakan salah atribut penentu sikap konsumen dodol buah hal ini dikarenakan atribut harga dodol buah memiliki pengaruh kuat dan ketergantungan antar atribut rendah. Harga dodol buah yang ada di UD. Putra Mandiri yaitu Rp.21.000 sampai Rp.25.000 per tas. Konsumen dodol buah di UD. Putra Mandiri merasakan adanya persamaan kualitas antara produk dodol buah dengan harga yang dibayarkan konsumen. Hal ini juga sesuai dengan pendapatan konsumen yang membeli dodol buah mayoritas merupakan konsumen dengan pendapatan tinggi yaitu besar dari Rp.4.500.000 per bulan. Hal ini berpengaruh terhadap daya beli konsumen dan harapan konsumen terhadap kualitas produk semakin meningkat yang membuat konsumen akan cendrung selektif dalam membeli produk.

Septiana (2010), menyatakan bahwa penetapan harga jual suatu produk oleh perusahaan haruslah mempertimbangkan aspek kualitas yang diberikan produk tersebut. Suatu produk harus memiliki kualitas produk yang baik didukung dengan harga jual yang kompetitif agar dapat bersaing. Konsumen 
menganggap bahwa harga jual produk sesuai dengan kualitas produk tersebut atau harga yang dikeluarkan konsumen untuk produk tersebut sama dengan kualitas yang didapatkan dari produk tersebut.

\section{Implikasi Pengembangan Pemasaran Dodol buah}

Kuadran kiri bawah (kuadran IV) memiliki pengaruh rendah terhadap kinerja sistem dan ketergantungan yang tinggi terhadap keterkaitan antar atribut sehingga menjadi output dalam sistem (Hardjomidjojo, 2002). Atribut-atribut tersebut yaitu kemasan 500, bentuk curah, harga murah, lisan, di gerai oleh-oleh. Sehingga atribut output yang diharapkan dari pengembangan pemasaran dodol buah di UD. Putra Mandiri adalah kemasan 500, bentuk curah, harga murah, lisan, di gerai oleh-oleh.

Kemasan 500 adalah barang yang sudah dikemas sebanyak 500 Gram atau setengah $\mathrm{Kg}$ yang menunjukkan bahwa banyaknya bobot dari produk tersebut. Pengemasan adalah sebuah sistem terkordinir yang dibuat untuk mempersiapkan barang supaya siap untuk didistribusikan, disimpan, dijual, dan dipakai.

Bentuk curah adalah komoditas yang ditangani, ditransportasikan, dan didistribusikan dalam jumlah besar dan tidak terkemas. Artinya penjualan curah masih dilakukan oleh pengrajin akan tetapi masih memiliki ketergantungan.

\section{Analisis Kriteria dalam Hirarki Keputusan}

Struktur hirarki pengelolaan pemasaran dodol buah, terdiri atas; tujuan (pengelolaan bauran pemasaran dodol buah), kriteria (produk, harga, promosi, distribusi), subkriteria (produk kemasan 250 gr, produk kemasan 500 gr, rasa, label halal, tanggal kadaluarsa, kemasan, produk selalu tersedia, harga murah, harga sesuai kemasan, harga sesuai kualitas, promosi lisan, mengikuti pameran, promosi melalui kemasan, distribusi ada di mana saja, di gerai oleh-oleh, di kios pengrajin, dan produk selalu tersedia) serta alter natif (penguatan kelembagaan pemasaran dan pengembangan bauran pemasaran). Lebih rinci pada Gambar 4.

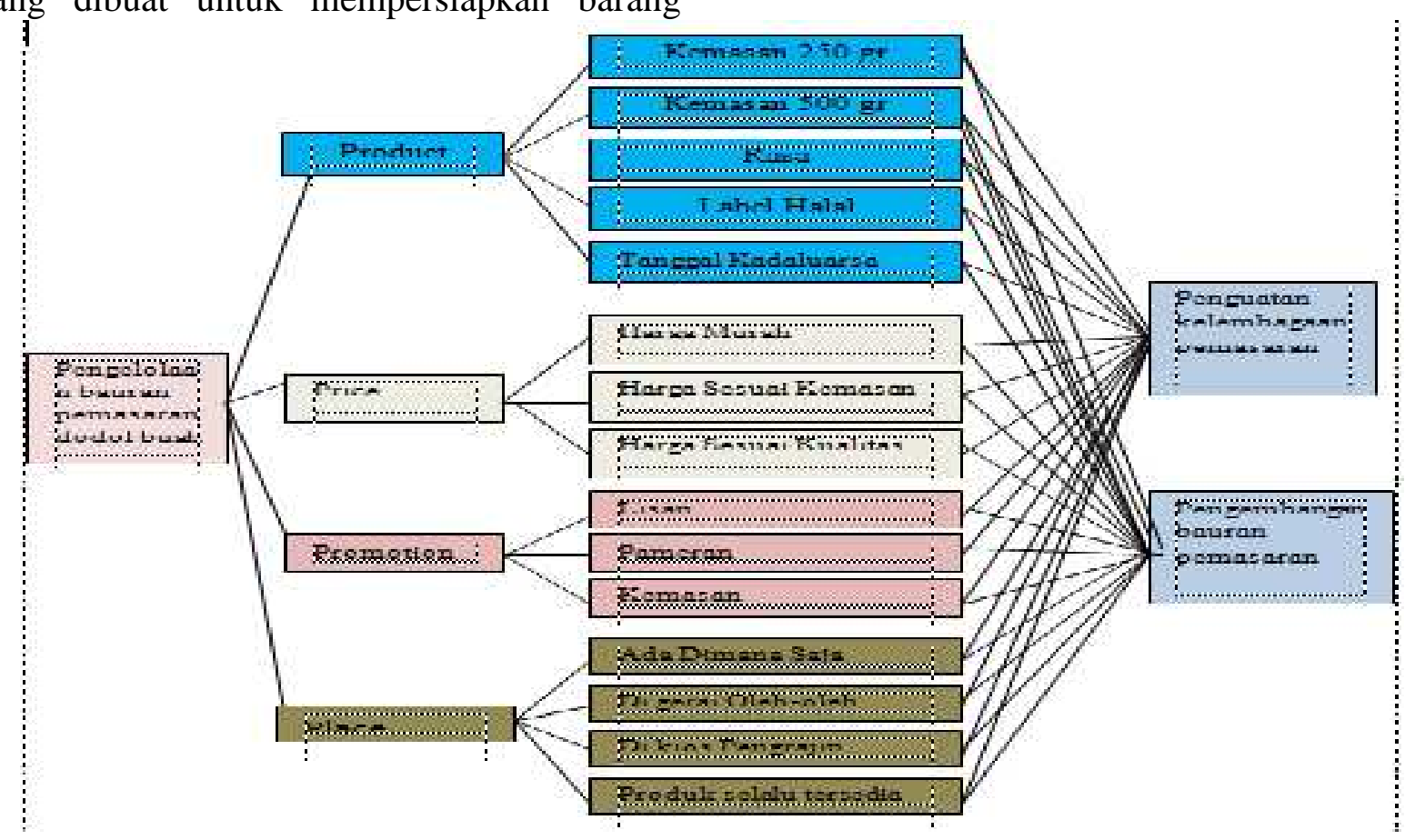

Gambar 4. Struktur Hirarki Pemasaran Dodol Buah 
Berdasarkan hasil analisis AHP dengan exper choice 2000 diperoleh bahwa alternatif I adalah penguatan kelembagaan pemasaran dodol buah dengan nilai 0,721 atau sekitar $72.1 \%$, dan alternatif II adalah pengelolaan bauran pemasaran produk dodol buah dengan nilai 0,461 atau sekitar $46.1 \%$ (Gambar 4). Nilai dari analisis AHP tersebut dapat diterima mengingat nilai rasio konsistensi yakni 0,0 atau kurang dari 0,1 (10\%). Menurut Saaty (2008), matriks perbandingan dapat diterima jika nilai rasio konsistensi <0,1. Penguatan kelembagaan pemasaran dodol buah dengan memprioritaskan pada atribut promosi melalui kemasan.

Shimp (2000) menyebutkan bahwa kegiatan promosi terdiri dari semua kegiatan pemasaran yang mencoba terjadinya aksi pembelian suatu produk yang cepat atau terjadinya pembelian dalam waktu yang singkat. Meliputi berbagai metode untuk

Priorities with respect to: promotion > kemasan mengkomunikasikan keunggulan, manfaat produk tertentu kepada pelanggan potensial dan aktual. Namun, untuk kemasan tas pada pengusaha dodol buah masih ada yang membuat konsumen sedikit bingung melihat merek dagangnya karena pada kemasan tas terlalu banyak rasa sehinga agak sulit menemukan rasa pada dagangnya rasa buah mangga, rasa buah naga dan lain sebagainya. Selain itu kelengkapan atribut kemasan lainnya seperti pencantuman masa kadaluarsa produk dan komposisi produk perlu ditambahkan. Perbaikan dalam kelembagaan pemasaran yang diperlukan adalah perlunya upaya negoisasi pengrajin khususnya dengan pedagang besar yang selama ini membeli dengan volume besar. Cooperative marketing can be a great opportunity or a headache, Natural Sources (2016). The cooperative members, however, were still constrained by the lack of a reliable market source and the lack of access to credit (Yeboah, 2005).

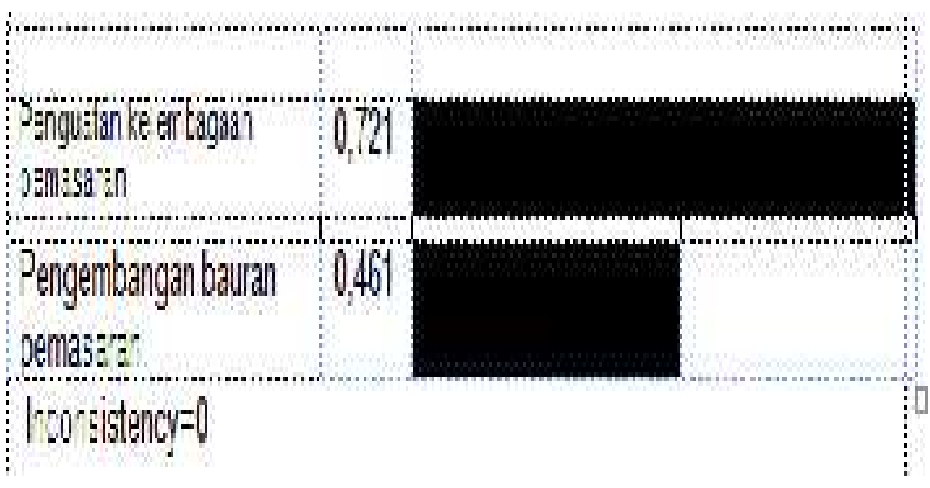

\section{KESIMPULAN}

Produk dodol buah unggulan dalam pemasaran dodol buah di Kabupaten Siak adalah buah pisang, nangka, jahe merah, labu manuis, lidah buaya, durian dan nanas. Peta hasil proses ALSCAL untuk menampilkan map MDS dari kasus di atas. Terlihat bahwa dodol buah naga terletak jauh dari keempat toko yang lain. Karena itu bisa dikatakan dodol buah naga paling berbeda jika dibandingkan dengan dua kelompok dodol durian yang lain. Dodol buah kacang hijau, ubi jalar dan mangga dianggap berada pada satu kuadran yang sama pula, sehingga keduanya juga bias dikatakan mirip. Dodol buah pisang, jahe merahm nangka dan labu manis dianggap berada pada satu kuadran yang sama pula, sehingga keduanya juga bias dikatakan mirip. Dodol lidah buaya, nanas dan durian dianggap berada pada satu kuadran yang sama pula, sehingga keduanya juga bias dikatakan mirip. 
Variable/atribut pengungkit dalam pengelolaan bauran pemasaran dodol buah di Kabupaten Siak diperoleh bahwa tipe sebaran cenderung mengumpul di kuadran I dan kuadran III. Tipe ini menunjukkan bahwa sistem yang dibangun stabil karena memperlihatkan hubungan yang kuat di mana variabel penggerak/ penentu mengatur variabel terikat dengan kuat. Atribut yang termasuk dalam variabel penentu (driving variables) terdiri atas; produk selalu ada, distribusi di kios pengrajin, tersedia di gerai oleh-oleh, tersedia dimana saja, dan promosi melalui kemasan. Atribut-atribut tersebut terletak di kuadran I, yakni atribut yang memiliki pengaruh kuat dan ketergantungan antar atribut rendah

Strategi pemasaran dodol buah di Kabupaten Siak kegiatan promosi terdiri dari semua kegiatan pemasaran yang mencoba terjadinya aksi pembelian suatu produk yang cepat atau terjadinya pembelian dalam waktu yang singkat. Meliputi berbagai metode untuk mengkomunikasikan keunggulan, manfaat produk tertentu kepada pelanggan potensial dan aktual

\section{Saran}

a) Sebaiknya konsumen dodol buah di UD. Putra Mandiri di Desa Buantan Besar mencari informasi mengenai produk dodol buah seperti informasi mengenai kemasan dan warna sebelum membeli dodol buah. Hal ini karena tidak semua dodol buah yang ada di UD. Putra Mandiri di Desa Buantan Besar memiliki kemasan dan warna yang sesuai.

b) Berdasarkan analisis sikap konsumen dengan analaisis prospektif produsen dodol buah di UD. Putra Mandiri di Desa Buantan Besar sebaiknya meningkatkan atribut yang diyakini konsumen sesuai dengan harapan konsumen yaitu promosi penjualan. c) Produsen dodol buah sebaiknya mempertahankan atribut yang diyakini konsumen sesuai dengan harapan konsumen yaitu citarasa, harga dodol buah, ukuran isi dan kepopuleran merek.

\section{DAFTAR PUSTAKA}

Baga LM dan M. Firdaus. 2011. Peran Cooperative Entrepreneur Dalam Pengembangan Program OVOP dan Pembiayaan Pertanian Berbasis Tanaman, Kasus Belimbing di Kota Depok. Di dalam: Baga LM, Fariyanti A, Jahroh S, editor. Kewirausahaan dan Daya Saing Agribisnis; [Waktu dan tempat tidak diketahui]. Bogor (ID): PT Penerbit IPB Press.

Bogadenta, Arya. 2013. The Secret Business Plan. Jogjakarta (ID): Penerbit Laksana.

Bourgeois, R. and Jesus, F. 2004. Participatory p ros pe c t ive a n a 1 y s i s. E x p l o r i n g and anticipating challenges with stakeholders. Center for Alleviation of Poverty through Secondary Crops Development in Asia and the Pacific, Monograph, 46, 1-29.

(BPS) Badan Pusat Statistik. 2005. konsumsi rataan makanan per kapita per bulan untuk makanan jadi di Kabupten Garut. Garut.

David, F. R. 2006. Manajemen Strategis. Edisi 10. Salemba Empat, Jakarta.

Departemen Pertanian. 2007. Produk Domestik Bruto Pertanian. Direktorat

Jenderal Bina Produksi Hortikultura, Jakarta. Departemen Pertanian. 2008. Ekspor 2003- 2006. http://www.Hortikultura.deptan.go.id/i ndex.php?option=com_content\&task= view\&id=134\&itemid=2 [24 Juni 2009] 
Departemen Pertanian. 2009. Program Pengembangan Kawasan Agropolitan. http://www.deptan.go.id/bpsdm/agrop olitan.htm [ 07 April 2009]

Firdaus, M. 2008. Manajemen Agribisnis. Jakarta (ID): Penerbit Bumi Aksara.

Haris, Abdi. 2008. Strategi Pemasaran Belimbing Manis (Averrhoa carambola L.) di Pusat Koperasi Pemasaran Belimbing Dewa Depok. Bogor (ID): Institut Pertanian Bogor.

Hubeis, M. dan M. Najib. 2008. Manajemen Strategik dalam Pengembangan Daya Saing Organisasi. PT Elex Media Komputindo, Jakarta.

Hubeis, M. 2013. Peran Ekonomi Kreatif Dalam Peningkatan Daya Saing Produk Pertanian. Bogor (ID): PT Penerbit IPB Press.

Kotler, P. 2002. Manajemen Pemasaran. edisi millenium jilid 1. PT. Prehallindo, Jakarta. 2002. Manajemen Pemasaran. edisi millenium jilid 2. PT. Prehallindo, Jakarta.

Kotler P dan Amstrong. 2003. Dasar-Dasar Pemasaran. Tim MarkPlus, penerjemah; Sarwiji B, editor. Jakarta (ID): PT Indeks Kelompok Gramedia. Terjemahan dari: Principles of Marketing. Ed ke - 9 .

Marimin. 2004. Teknik dan aplikasi pengambilan keputusan kriteria majemuk. Jakarta: Gramedia Widiasarana Indonesia.

Nurmalina R et al. 2010. Studi Kelayakan Bisnis. Bogor (ID): Lembaga Penerbit Departemen Agribisnis Fakultas Ekonomi dan Manajemen Institut Pertanian Bogor.
Saaty, T.L. 2008. Decision making with the analytic hierarchy process: Int.J. Services, 1(1), 83-98.

Solihin, I. 2007. Memahami Business Plan. Jakarta (ID): Penerbit Salemba Empat.

Umar, H. 2007. Studi Kelayakan Bisnis. Jakarta (ID): PT Penerbit Gramedia Pustaka Utama.

Umar, H. 2008. Strategic management in Action. PT Gramedia Pustaka Utama, Jakarta 